\title{
Manganese Removal Status by Arsenic Removal Technologies Available in Bangladesh: Manganese Removal Treatment by Sodium Hypochlorite
}

\author{
S. Siraj*, A. I. Kazi, S. Ahmed, M. A. Akbor and A. Ahsan \\ Analytical Research Division, Bangladesh Council of Scientific and Industrial Research, \\ Dr. Qudrat-i-Khuda Road, Dhanmondi, Dhaka-1205, Bangladesh
}

\begin{abstract}
In addition to arsenic, the groundwater in Bangladesh is often found to be contaminated with manganese whose permissible limit set by WHO being $400 \mathrm{ppb}$ in drinking water. Since most arsenic removal technologies (ARTs) are designed to remove As and not to remove Mn, during field testing and verification of performance of ARTs under the Bangladesh Environmental Technology Verification-Support to Arsenic Mitigation (BETV-SAM) project of BCSIR, it has been found that only the Sono technology using $\mathrm{Fe}^{0}$ as arsenic removal medium which can also remove Mn to produce Mn safe drinking water but others such as Alcan, Read-F household, Sidko, Nelima, Shawdesh cannot. During field testing of these technologies under the BETV-SAM project, it has been attempted to treat Mn by a traditional chlorine oxidation method to produce Mn safe drinking water. Concentrations of dissolved As (T), As (III), Fe, Mn and pH in the considered well water for manganese treatment were in ranges of 125 - $1247 \mathrm{ppb}, 116$ - $1127 \mathrm{ppb}, 1.40$ - $15.5 \mathrm{ppm}, 505-2245 \mathrm{ppb}$ and 7.0 to 7.5 , respectively. The required chlorine dose and time for treatment of manganese in $20 \mathrm{~L}$ water have been found to be $6.2-12.4 \mathrm{ppm}$ and $1-2 \mathrm{~h}$, respectively.
\end{abstract}

Keyword: Arsenic, Manganese, ART, Verification, Chlorine, Iron.

\section{Introduction}

Manganese is a naturally occurring element that can be found ubiquitously in the air, soil, and water. Manganese is an essential nutrient for human and animals (Leach and Harris, 1997). Adverse health effects can be caused by inadequate intake or over exposure (Keen et. al., 2000). The chronic ingestion of $\mathrm{Mn}$ in drinking water is associated with neurologic damage (Kondakis et. al., 1989). Manganese normally does not occur as a free metal but mostly in the forms of oxides, sulfides, carbonates and silicates (Post, 1999). One major cause of manganese mobilization in aquifers is reductive decomposition and dissolution of compounds such as $\mathrm{Mn}-\mathrm{OOH}, \mathrm{MnO}_{2}$ and $\mathrm{MnS}$ (Buamah et.al., 2008). One national scale survey (Frisbie et. al., 2002) on tube well water in large areas of Bangladesh for toxic elements has revealed that manganese concentration in most sample exceeds WHO health based drinking water guidelines. About $78 \%$ of tube wells at western areas of Bangladesh give water containing manganese concentration exceeding WHO's recommended level (Frisbie et. al., 2009).

\footnotetext{
* Corresponding author: E-mail: shajahansalim@yahoo.com
}

A national scale study (Frisbie et. al., 2002) indicates that $\sim 50 \%$ of the area of Bangladesh contains groundwater with $\mathrm{Mn}$ concentration greater than $400 \mathrm{ppb}$. Another national scale study (BGS and DPHE, 2001) based on 3,530 samples suggests that $35 \%$ tube well of Bangladesh deliver water contaminated with manganese.

Manganese can be removed by aeration followed by sand filtration, chemical oxidation using strong oxidants, biological filtration through bacteria in water and chelation (Ming et. al., 2003). This paper reports the results of the manganese removal status of verified ARTs in Bangladesh and also describes the process of manganese removal by chlorine oxidation followed by flocculation, settling and filtration. Batch tests have been carried out to optimize oxidant doses and time for maximum removal of manganese. The treated water is then applied to ARTs for removal of arsenic. This study will lay the foundation for the development of new module to add with arsenic removal technologies to provide arsenic and manganese safe drinking water. 


\section{Materials and Methods}

\section{Site selection}

The Technology Performance Monitoring (TPM) Program was designed to assess the long term performance of four ARTs (Sono, Read-F, Sidko and Alcan) over a period of one year to examine whether these systems would be efficient to manganese removal beside arsenic from ground water or not. The Program deployed the technology units in Manikganj, Balagonj, Jhikargacha, Bera and Chapai to treat different water matrices. Two other technologies, namely, Nelima and Shawdesh were verified by deploying those in Dohar, Chandina, Begumgonj, Ishwardi and Chapai and tested for 6.5 months and 15 - 20 days, respectively. The areas were chosen on the basis of their groundwater quality parameters.

\section{Technology operation and sample collection}

Technologies were operated and their performance were closely monitored by the hired testing agency's field crews on analyzing raw and treated water for different water quality parameters including manganese using field test kits ; and on collecting and sending samples of raw and treated water at regular intervals to designated laboratories to analyze different water quality parameters. Metals were quantified by ICP-MS or AAS in Bangladesh and Canada. Raw and treated water samples were collected in $500 \mathrm{~mL}$ clean plastic bottles. Samples were taken and shipped to analytical laboratories after preserving with nitric acid $(\mathrm{pH}<2)$.

\section{Field testing procedure during Mn removal processing}

During field testing and monitoring of the performance of ARTs, it is seen that only Sono technology can remove manganese from ground water to produce manganese safe drinking water. The project includes then to develop the method for manganese removal before treating by ARTs for providing both arsenic and manganese safe drinking water. Commercially available bleach $5.25 \%$ sodium hypochlorite (clotec) has been used for manganese removal. Hypochlorite oxidizes dissolved manganese to insoluble $\mathrm{MnO}_{2}$ according to the following reaction; $\mathrm{Mn}^{2+}+\mathrm{ClO}^{-}+\mathrm{H}_{2} \mathrm{O} \rightarrow \mathrm{MnO}_{2}+$ $\mathrm{Cl}^{-}+2 \mathrm{H}^{+}$. Manganese in raw water and in treated water has been measured by the Hach test kit method in which permanganate color is produced based on following reaction: $5 \mathrm{IO}_{4}{ }^{-}$ $+8 \mathrm{MnO}+4 \mathrm{H}_{2} \mathrm{O} \rightarrow 5 \mathrm{I}^{-}+8 \mathrm{H}^{+}+8 \mathrm{MnO}_{4}^{-}$and the colour is compared with a color comparator to quantify manganese.
It is important to note that chlorine also oxidises Fe(II) dissolved in well water to $\mathrm{Fe}$ (III) together with oxidation of some dissolved organic matters. Ferric ion is hydrolysed to ferric hydroxide, which coagulates to trap suspended $\mathrm{MnO}_{2}$ and ultimately facilitates its removal. In order to optimize oxidation condition to remove manganese efficiently, the amount of chlorine requirement has to be determined experimentally in the field for individual well water. The procedure for the removal of manganese from water has been established based on following steps:

i. The well was purged and then water samples were collected in four buckets of approximately $20 \mathrm{~L}$ each and labelled.

ii. $5,7,9$ and $11 \mathrm{~mL}$ of $5.25 \%$ sodium hypochlorite solution were added to labelled buckets. $1 \mathrm{~mL}$ of commercially available bleach (5.25\% sodium hypochlorite solution) contains $52 \mathrm{mg}$ sodium hypochlorite. Thus, $1 \mathrm{~mL}$ of bleach in $20 \mathrm{~L}$ of well water is equivalent of about 2.6 $\mathrm{ppm}$ of sodium hypochlorite or $\sim 1.24 \mathrm{ppm}$ chlorine.

iii. Water in each bucket was mixed well and allowed to stand for half an hour. The mixing and standing were repeated three times.

iv. Samples of supernatant were taken from each bucket after $0.5,1.0,1.5$ and $2.0 \mathrm{~h}$ and analysed for chlorine and manganese contents in each sample using Hach field test kits in order to specify minimum dose and conditioning time for effective manganese removal.

v. The treated water was filtered through a fourfold poplin cloth filter to treat again by ART to obtain water containing below $50 \mathrm{ppb}$ As and $0.4 \mathrm{ppm} \mathrm{Mn}$.

\section{Results and Discussion}

\section{Manganese removal status by ARTs used in Bangladesh}

The performance of ARTs available in Bangladesh towards manganese removal from manganese contaminated tube well waters of some localities have been examined and presented as histograms in fig. 1-5 for Sono, Read-F household, Alcan, Shawdesh Aqua Filter (SAF) and Sidko, respectively. It is seen that only Sono ART using $\mathrm{Fe}^{0}$ can effectively remove manganese to levels below prescribed maximum permissible limit of WHO (400 ppb). The reason for effectiveness of Sono technology regarding manganese removal is probably the formation of $\mathrm{H}_{2} \mathrm{O}_{2}$ by the following reactions 
which oxidizes dissolved manganese to insoluble $\mathrm{MnO}_{2}$ :

$2 \mathrm{Fe}+\mathrm{O}_{2}+4 \mathrm{H}^{+} \rightarrow 2 \mathrm{Fe}(\mathrm{OH})_{2}$ (Matheson and Tratnyek, 1994)

$2 \mathrm{Fe}(\mathrm{OH})_{2}+\mathrm{O}_{2}+2 \mathrm{H}_{2} \mathrm{O} \rightarrow 2 \mathrm{Fe}(\mathrm{OH})_{3}+\mathrm{H}_{2} \mathrm{O}_{2} \quad$ (Stumm and Morgan, 1996)

$\mathrm{Fe}^{0}+\mathrm{O}_{2}+2 \mathrm{H}^{+} \rightarrow \mathrm{Fe}^{2+}+\mathrm{H}_{2} \mathrm{O}_{2} \quad$ (Voegelin and Hug, 2003 ; Joo et. al., 2004)

The Fig. 2 shows that Read-F ART using cerium oxide impregnated ethylene-vinyl alcohol has limited capability for the removal of manganese. The fraction of Mn removed varies from unit to unit and is insignificant most cases. This makes the technology unsuitable to treat groundwater containing $\geq 0.4 \mathrm{mg} / \mathrm{L}$ of $\mathrm{Mn}$.

The performance of Alcan ART towards manganese removal is shown in Fig. 3. Alcan ART using activated alumina has limited capability for the removal of manganese. The fraction of Mn removed varies from unit to unit and is insignificant in most cases as in Read-F household. This makes the technology unsuitable for Mn removal.

Figure 4 shows that Shawdesh Aqua Filter (SAF) adds manganese to the treated water. The technology uses chlorine as oxidant to arsenic and ferric sulfate as coagulant. It has been seen that the additional source of manganese is ferric sulfate which contains about $0.06 \% \mathrm{Mn}$.

On the other hand, Fig. 5 represents the efficiency of the removal by Sidko ART which uses granular $\mathrm{Fe}(\mathrm{OH})_{3}$. The efficiency is not at all acceptable.

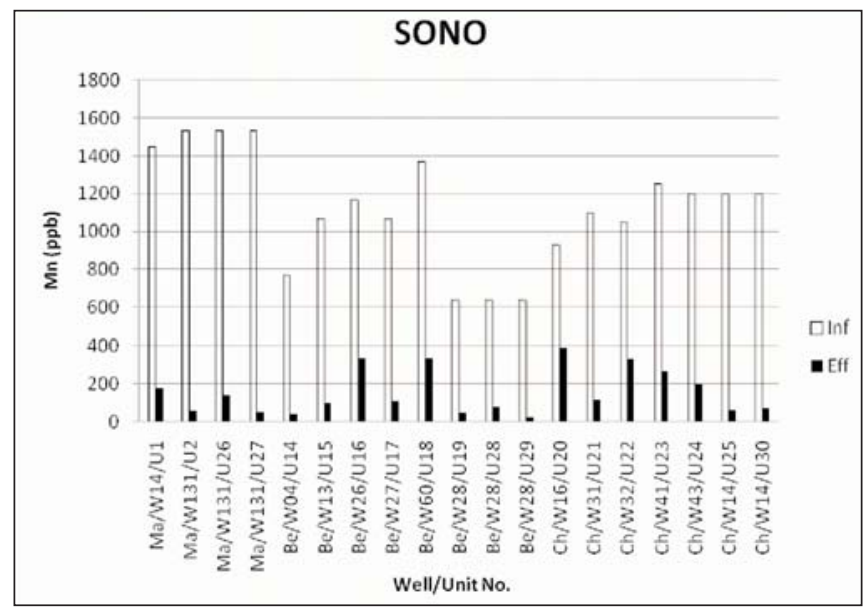

Fig 1: Manganese removal status by Sono: Ma- Manikganj, Be- Bera, Ch- Chapai

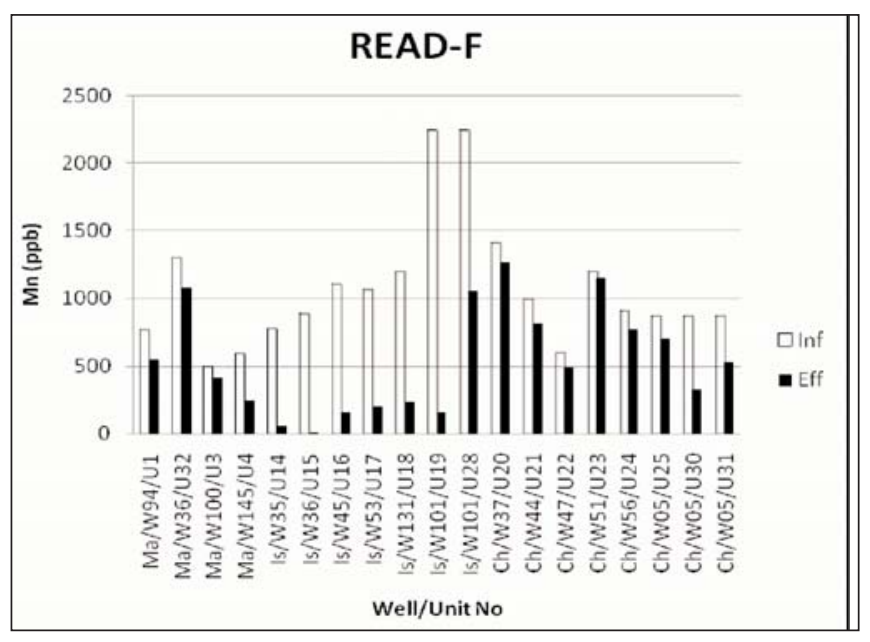

Fig 2: Manganese removal status by Read-F: Ma- Manikganj, Is- Ishwardi, Ch- Chapai

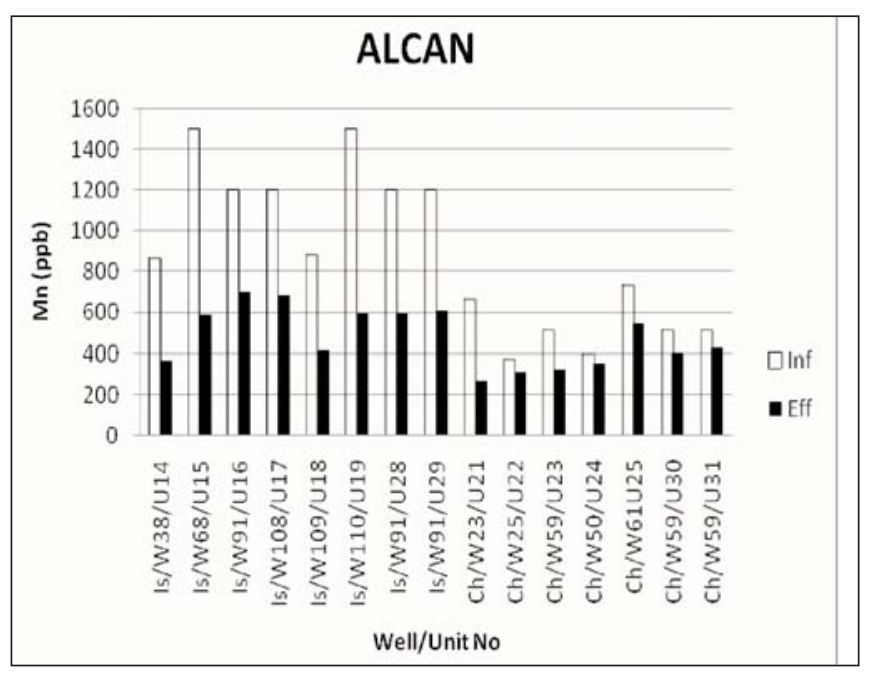

Fig 3: Manganese removal status by Alcan: Is- Ishwardi, Ch- Chapai

Figure 6 shows the variation of Mn concentration in effluent with cumulative volume of treated water. It is seen that this technology can remove manganese at the initial stages of its performance but the concentration of $\mathrm{Mn}$ in the treated water increases with increasing cumulative volume of treated water and reaches a plateau (exceptional from other technologies). These results demonstrate that Nelima ART (using granular $\mathrm{Fe}(\mathrm{OH})_{3}$ as media) cannot treat groundwater containing $\geq 0.4 \mathrm{mg} / \mathrm{L}$ of manganese. It is noted that the concentrations of manganese in influent water of Nelima ARTs were 1750, 1050, 1150, 955, 565 ppb in Chapai, Dohar, Ishwardi, Begumgonj and Chandina, respectively. 


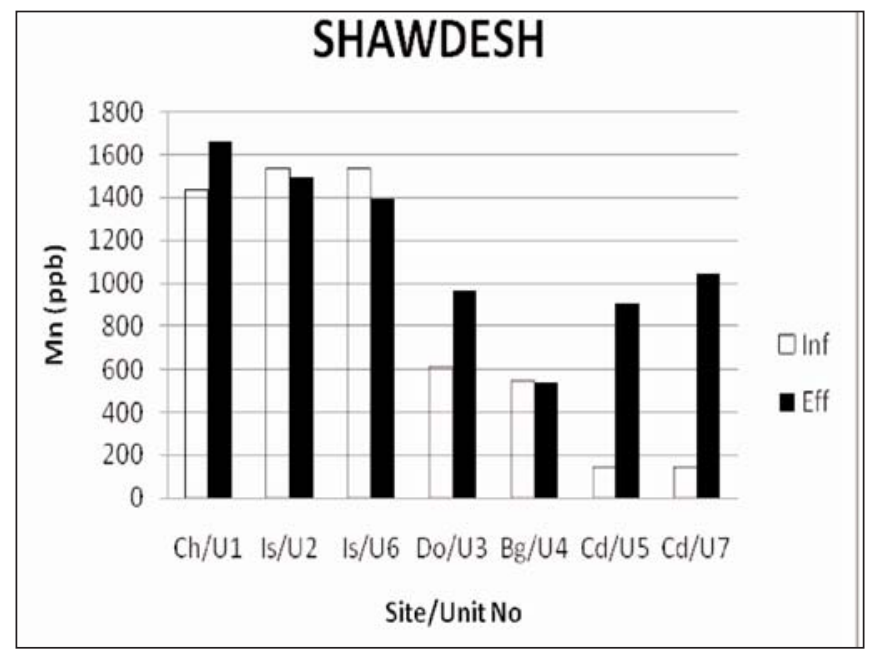

Fig 4: Manganese removal status by Shawdesh: Ch- Chapai, Is- Ishwardi, Do- Dohar, Bg- Begumgonj, Cd-Chandina

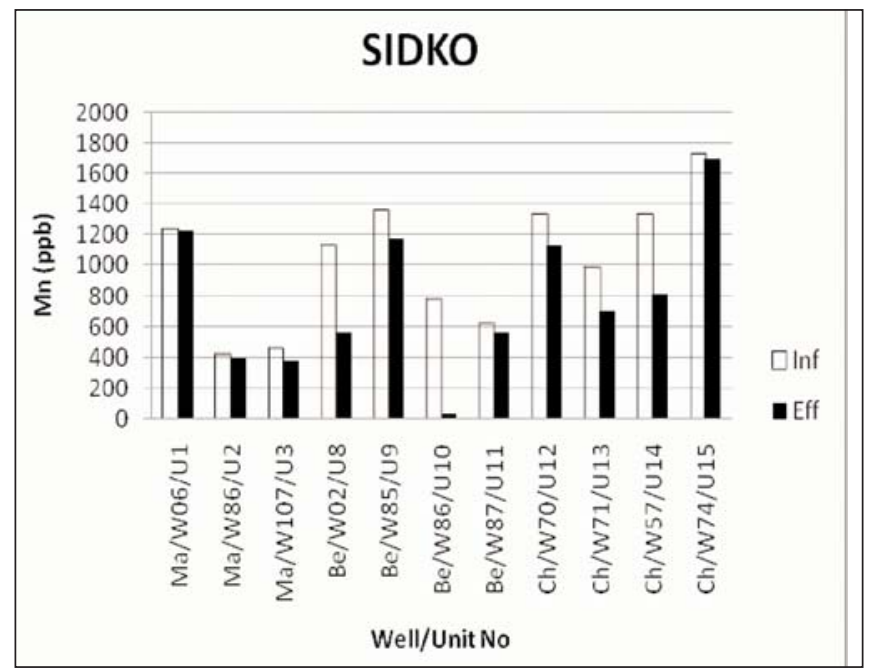

Fig 5: Manganese removal status by Sidko: Ma- Manikganj, Be- Bera, Ch- Chapai

It is therefore concluded that the ARTs used in Bangladesh excepting Sono technology is not suitable for efficient manganese removal from manganese contaminated water. So it is recommended for the prior treatment of manganese contaminated water for its removal followed by the application of ARTs except Sono.

\section{Manganese removal from manganese contaminated water}

The Table I shows the results on the Mn-content in NaOCltreated groundwater. The ground water containing $472 \mathrm{ppb}$

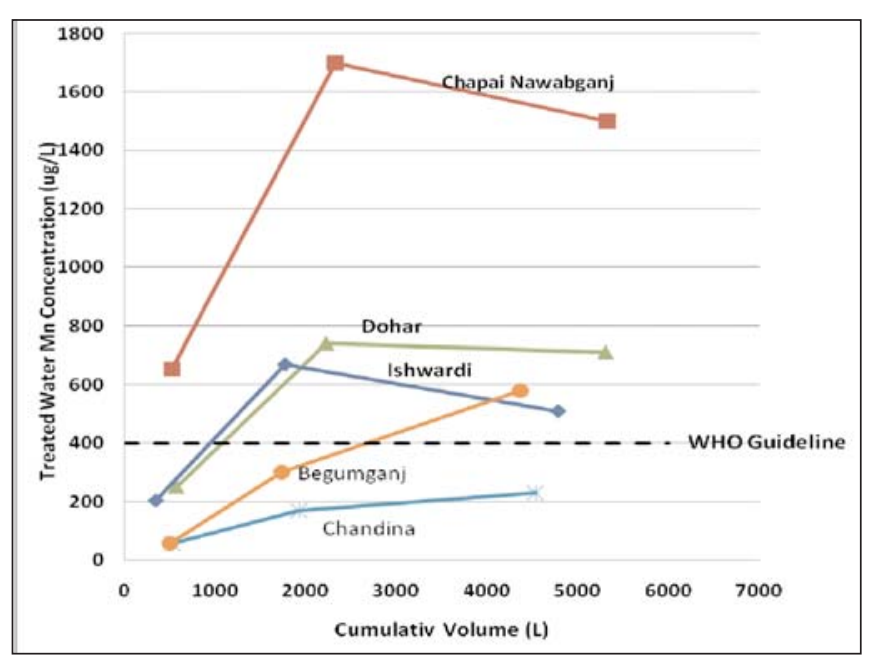

Fig. 6: Plots showing variation of Mn concentration in effluent at various cumulative volume of treated water.

arsenic (T), $401 \mathrm{ppb}$ arsenic (III), $15.5 \mathrm{ppm}$ iron and 1300 ppb manganese (W36 of Manikgonj) has been examined for Mn-removal by bleaching. The optimum time need for the treatment and manganese and chlorine contents in treated water have been determined. The data show that $7 \mathrm{~mL}$ of clotec i.e, $8.68 \mathrm{ppm}$ of chlorine treatment for $2 \mathrm{~h}$ is required to treat the water to bring the manganese and chlorine to the allowable limit as prescribed by WHO ( $\mathrm{Mn}<400 \mathrm{ppb}$ and $\mathrm{Cl}_{2}<5$ ppm). Manganese and chlorine contents of treated water were measured at field site using test kits. Sample preparation for these tests included filtration of treated water with fourfold poplin cloth. Some Mn containing flocs might have been passed through the filter to mix with the filtrate. This might be the reason for minor inconsistency in Mn contents of a few treated water samples after successive time intervals. However, these few inconsistent data were omitted as outlier considering unavoidable field experimental error and the remaining test data were used to draw conclusion in respect of making the treated water Mn-safe. 2 out of 16 chlorine content data of treated water samples were found inconsistent. These two chlorine content data were also treated as outliers and the rest considerd were to draw conclusion on Clotec dosing for Mn-removal. Table II shows the results on hypochlorite treatment of other wells of different localities in Bangladesh. The amount of chlorine required to treat water from different wells are different because of the fact that different well water contains different amounts of dissolved arsenic(III), iron which all consume chlorine to oxi- 
dize themselves to higher oxidation states. So it is proved that chlorine dose for treating manganese for different wells should be determined individually. must also be addressed and if both the contaminants are treated by the single technology then people in contaminated areas get rid of more difficulties.

Table I: Treatment of manganese in water by chlorine at technology verification site

\begin{tabular}{|c|c|c|c|c|c|c|c|c|c|c|}
\hline \multirow{3}{*}{$\begin{array}{c}{[\mathrm{Mn}] \text { in sample }} \\
(\mathrm{ppb})\end{array}$} & \multirow{3}{*}{$\begin{array}{l}\text { Clotec dose } \\
\text { in } 20 \mathrm{~L} \\
\text { well water } \\
(\mathrm{mL})\end{array}$} & \multirow{3}{*}{$\begin{array}{l}\text { Amount of } \\
\text { chlorine } \\
\text { added } \\
(\mathrm{ppm})\end{array}$} & \multicolumn{8}{|c|}{ Concentration after } \\
\hline & & & \multicolumn{2}{|c|}{$30 \mathrm{~min}$ of } & \multicolumn{2}{|c|}{$60 \mathrm{~min}$ of } & \multicolumn{2}{|c|}{90 min of } & \multicolumn{2}{|c|}{$120 \mathrm{~min}$ of } \\
\hline & & & $\begin{array}{c}\mathrm{Mn} \\
(\mathrm{ppb})\end{array}$ & $\begin{array}{c}\mathrm{Cl}_{2} \\
(\mathrm{ppm})\end{array}$ & $\begin{array}{c}\mathrm{Mn} \\
(\mathrm{ppb})\end{array}$ & $\begin{array}{c}\mathrm{Cl}_{2} \\
(\mathrm{ppm})\end{array}$ & $\begin{array}{c}\mathrm{Mn} \\
(\mathrm{ppb})\end{array}$ & $\begin{array}{c}\mathrm{Cl}_{2} \\
(\mathrm{ppm})\end{array}$ & $\begin{array}{c}\mathrm{Mn} \\
(\mathrm{ppb})\end{array}$ & $\begin{array}{c}\mathrm{Cl}_{2} \\
(\mathrm{ppm})\end{array}$ \\
\hline \multirow{4}{*}{1300} & 5 & 6.20 & 650 & 0.1 & 650 & 0.1 & 600 & 0.1 & 550 & 0.1 \\
\hline & 7 & 8.68 & 850 & 0.1 & 550 & 0.4 & 600 & ND & 300 & ND \\
\hline & 9 & 11.2 & 450 & 2.4 & 700 & 0.9 & 600 & 0.7 & 250 & 0.6 \\
\hline & 11 & 13.6 & 600 & 2.6 & 500 & 2.0 & 550 & 1.8 & 100 & 2.6 \\
\hline
\end{tabular}

Table II: Required chlorine dose and time required for treatment of manganese for different manganese contaminated wells

\begin{tabular}{|c|c|c|c|c|c|c|c|c|c|c|}
\hline \multirow[b]{2}{*}{ Site/Well Id } & \multicolumn{5}{|c|}{ Composition of raw water } & \multirow{2}{*}{$\begin{array}{c}\text { Clotec } \\
\text { dose, } \\
\mathrm{mL} / 20 \mathrm{~L} \\
\text { wel } \\
\text { water }\end{array}$} & \multirow{2}{*}{$\begin{array}{l}\text { Clotec } \\
\text { added } \\
\text { (ppm) }\end{array}$} & \multirow{2}{*}{$\begin{array}{l}\text { Treat } \\
\text { ment } \\
\text { time } \\
(\mathrm{h})\end{array}$} & \multirow{2}{*}{$\begin{array}{l}\text { Mn in } \\
\text { treated } \\
\text { water } \\
(\mathrm{ppb})\end{array}$} & \multirow{2}{*}{$\begin{array}{c}\mathrm{Cl}_{2} \\
\text { treated } \\
\text { water } \\
(\mathrm{ppm})\end{array}$} \\
\hline & $\begin{array}{c}\mathrm{As} \\
(\mathrm{ppb})\end{array}$ & $\begin{array}{c}\text { As } \\
\text { (III) } \\
\text { (ppb) }\end{array}$ & $\underset{(\mathrm{ppm})}{\mathrm{Fe}}$ & $\begin{array}{c}\mathrm{Mn} \\
(\mathrm{ppb})\end{array}$ & $\mathrm{pH}$ & & & & & \\
\hline Ishwardi/W131 & 392 & 333 & 1.4 & 1200 & 7.2 & 5.0 & 6.2 & 1 & 400 & 2.0 \\
\hline Manikganj/W100 & 125 & 116 & 12.5 & 505 & 7.1 & 5.0 & 6.2 & 1 & 350 & ND \\
\hline Chapai/W37 & 203 & 192 & 2.55 & 1404 & 7.0 & 6.0 & 7.4 & 1 & ND & 1.2 \\
\hline Ishwardi/W101 & 799 & 687 & 2.72 & 2245 & 7.4 & 6.0 & 7.4 & 1 & ND & 3.0 \\
\hline Manikganj/W36 & 472 & 401 & 15.5 & 1300 & 7.5 & 7.0 & 8.7 & 2 & 300 & ND \\
\hline Ishwardi/W89 & 1247 & 1127 & 4.2 & 2200 & 7.2 & 8.0 & 9.9 & 2 & 300 & 0.5 \\
\hline Manikganj/W14 & 423 & 342 & 7.38 & 1445 & 7.2 & 10.0 & 12.4 & 1 & 250 & 2.0 \\
\hline
\end{tabular}

\section{Conclusion}

The above discussion will carry a message to the arsenic removal technology users and the technology owner that the technology which is unable to remove manganese should not under any circumstances be used to treat groundwater containing $>0.4 \mathrm{mg} / \mathrm{L}$ of manganese.

i. Sono, the only technology among the certified arsenic removal technologies in Bangladesh can remove $\mathrm{Mn}$ from Mn contaminated groundwater and can produce Mn safe drinking water consistently.

ii. Mitigation efforts should not be limited to arsenic by arsenic removal technologies, the health risks from manganese in the contaminated region's drinking water iii. The manganese removal procedure developed shows the path that if the arsenic removal technology proponent set a separate module with the technology to treat manganese then the users may get both arsenic and manganese safe drinking water in contaminated areas.

iv. Commercially available $5.25 \%$ clotech solution (Sodium hypochlorite) can be used to treat ground water for manganese removal.

v. Same chlorine dose can't be prescribed to treat manganese in water from all contaminated areas. It will vary from well to well since the concentration of dissolve arsenic (III), iron, manganese and other water quality parameters are different and many of these constituents will consume chlorine. 


\section{Acknowledgements}

The authors wish to offer thanks to all staff of BETV-SAM project. Thanks go to Canadian International Development Agency (CIDA) for financing this project.

\section{References}

BGS and DPHE (2001). Arsenic Contamination of Groundwater in Bangladesh. Eds: Kinniburgh, D.G. and Smedley P. L. British Geological Survey Technical Report, WC/00/19. Four volumes.

Buamah R., Petrusevski B. and Schippers J. C. (2008). Presence of arsenic, iron and manganese in groundwater within the gold-belt zone of Ghana. J. Water Supply: Res.Tech., 57: 519-529.

Frisbie S. H., Ortega R., Maynard D. M. and Sarkar B. (2002). The concentrations of arsenic and other toxic elements in Bangladesh's drinking water. Environ. Health Persp., 110:1147-1153.

Frisbie S. H., Mitchell E. J., Mastera L. J., Maynard M. D., Yusuf A. Z., Siddiq M. Y., Ortega R., Dunn R. K., Westerman D. S., Bacquart T. and Sarkar B. (2009). Public health strategies for western Bangladesh that address arsenic, manganese, uranium, and other toxic elements in drinking water. Environ. Health Persp., 117: 410-416.

Joo S. H., Feitz A. J. and Waite T. D. (2004). Oxidative degradation of the carbothioate herbicide, molinate, using nanoscale zero-valent iron. Environ. Sci. Technol., 38: 2242-2247.

Keen C. L., Ensunsa J. L. and Clegg M. S. (2000). Manganese metabolism in animals and humans including the toxicity of manganese. Met. Ions Biol. Syst., 37: 89-121.
Kondakis X. G., Makris N., Leotsinidis M., Prino M. and Papapetropoulos T. (1989). Possible health effects of high manganese concentration in drinking water. Arch. Environ. Health, 44:175-178.

Leach R. M. and Harris E. D. (1997). Manganese. Clinical Nutrition in Health and Disease, 2 Handbook of Nutritionally Essential Mineral Elements), Marcel Dekker: New York, 335-355.

Matheson L. J. and Tratnyek P. G. (1994). Reductive dehalogenation of chlorinated methane by iron metal. Environ. Sci. Tech., 28: 2045-2053.

Ming T., Liang D., Liang Y., Qiang W. and Liang Z. (2003). Reduction of Mn content in municipal water supply by permanganate. J.Water Supply and Treatment. China, 29: $30-32$.

Post E. P. (1999). Manganese oxide minerals: crystal structures and economic and environmental significance. Proc. Natl. Acad. Sci. USA. 96: 3447-3454.

Stumm W. And Morgan J. J. (1996). Aquatic Chemistry, John Wiley and Sons, Inc: New York, 426

Voegelin A. and Hug S. J. (2003). Catalyzed oxidation of arsenic(III) by hydrogen peroxide on the surface of ferrihydrite: an in-situ ATR-FTIR study. Environ. Sci. Technol., 37: 972-978.

WHO (1993). Guidelines for Drinking-Water Quality, Vol 1: Recommendations, 2nd ed. Geneva: World Health Organization, 39-57, 174.

WHO (1998). Guidelines for Drinking-Water Quality, Addendum to Vol 1: Recommendations, 2nd ed. Geneva: World Health Organization, 3-12, 34.

Received :May 18, 2008;

Accepted : Febuary 06, 2011 